\title{
Demersal ichthyofaunal distribution in the abyssal North Atlantic revisited: the effect of sample size on ordination
}

\author{
N. R. Merrett ${ }^{1, *}$, M. J. R. Fasham ${ }^{2}$ \\ ${ }^{1}$ Zoology Department, The Natural History Museum, Cromwell Road, London SW7 5BD, United Kingdom \\ ${ }^{2}$ Southampton Oceanography Centre, Empress Dock, Southampton, Hampshire SO14 3ZH, United Kingdom
}

\begin{abstract}
Abyssal benthic trawling is time-consuming and therefore costly. In practice, such sampling to elucidate demersal fish ecology accrues largely opportunistically over long periods. Thus, it was that striking contrasts in fish morphology, ultimate size, feeding pattern and fecundity were identified across a north-south boundary zone in the eastern North Atlantic from 12 samples. The results were later refined with the addition of a further 13 samples. Now, collection of a further 20 samples, making a total of 45 , has broadened spatial coverage further. This has led to former sample groupimgs coalescing to complicate initial indications and published interpretations, although confirming the major findings. Hence, evidence of the influence of latitude on sample composition (together with that on the biological characteristics of the dominant species) was strengthened (consistent with response to changes in overlying productivity suggested initially). Yet the influence of bathymetry on sample composition was considerably weakened, although remaining significant, especially along latitude $31^{\circ} \mathrm{N}$ close to the zone of ichthyofaunal change.
\end{abstract}

KEX WORDS: Abyssal ichthyofauna - Distribution - MDS ordination - Sample size $\cdot$ NE Atlantic

\section{INTRODUCTION}

'Logistical difficulties associated with sampling the abyssal ocean floor at 4000-6000 m depth have meant that this region, the largest habitat on Earth $153 \%$ global surface area [Sündermann 1986]), is by far the most poorly known. The difficulties concern largely ship suitability; few research vessels are available with a winch capacity containing the $15000 \mathrm{~m}$ or so of trawl wire necessary to fish below $4000 \mathrm{~m}$ depth. The attendant operating costs are high and often limit the available shiptime, since something less that two samples per day are recoverable from such great depths' (Merrett \& Haedrich 1997). These difficulties associated with the physical collection of data can have a subsequent effect on their interpretation.

Nonetheless, Sulak $(1982 ; 13$ samples from below $4000 \mathrm{~m}$ in the Bahamas, 4 samples from the Middle

•E-mail:n.merrett@nhm.ac.uk
Atlantic Bight) and Anderson et al. $(1985 ; 28$ samples from the Caribbean) assembled such data, and from them identified differences in the faunal composition below $2000 \mathrm{~m}$ with respect to dominant species among these 3 regions of the western basin of the North Atlantic. These authors then related the ecology of the species collected to the respective overlying oligotrophic and eutrophic regimes of primary production.

Published work on assemblage structure of the abyssal demersal fish in the eastern basin of the North Atlantic (Merrett 1987; 12 samples $>4000 \mathrm{~m}$ ), complemented by the addition of further data (Merrett 1992; 13 samples opportunistically obtained to consolidate the earlier findings and to extend regional coverage $[12+13=25$ samples]], had indicated an abyssal zone arguably structured by the overlying productivity regime. It was influenced also by bathymetric variation, even within the 4000 to $5400 \mathrm{~m}$ stratum investigated. Now a further 20 comparable trawl samples have been added (making a total of 45), and these modify the picture once again. 
Table 1. Condensed sampling data and dominant species per trawl haul for 45 stations from the abyssal eastern North Atlantic

\begin{tabular}{|c|c|c|c|c|c|c|c|}
\hline $\begin{array}{l}\text { Serial } \\
\text { no. }\end{array}$ & $\begin{array}{l}\text { Station } \\
\text { no. }\end{array}$ & $\begin{array}{c}\text { Latitude } \\
{ }^{\circ} \mathrm{N}\end{array}$ & $\begin{array}{l}\text { Longitude } \\
{ }^{\circ} \mathrm{W}\end{array}$ & $\begin{array}{l}\text { Depth } \\
(\mathrm{km})\end{array}$ & $\begin{array}{l}\text { Samp } \\
\text { Spp. rich. }\end{array}$ & Abundance & Dominant species \\
\hline 1 & 913101 & 20 & 21 & 4 & 5 & 19 & Coryphaenoides (Lionurus) carapinus \\
\hline 2 & 1065201 & 37 & 11 & 5.1 & 7 & 38 & Echinomacrurus mollis \\
\hline 3 & 1111601 & 47 & 15 & 4 & 8 & 35 & Coryphaenoides (Nematonurus) armatus \\
\hline 4 & 1111801 & 45 & 18 & 4.6 & 8 & 26 & Coryphaenoides (Chalinura) profundicolus \\
\hline 5 & 1112114 & 41 & 21 & 4.1 & 10 & 95 & Coryphaenoides (Chalinura) leptolepis \\
\hline 6 & 1113401 & 34 & 18 & 4.8 & 15 & 43 & Bathypterois longipes \\
\hline 7 & 1126152 & 31 & 25 & 5.4 & 11 & 41 & Bathymicrops regis \\
\hline 8 & 1126158 & 31 & 25 & 5.4 & 7 & 41 & Bathypterois longipes \\
\hline 9 & 1126144 & 31 & 25 & 5.4 & 9 & 59 & Bathymicrops regis \\
\hline 10 & 1155301 & 22 & 21 & 4.5 & 6 & 10 & Coryphaenoides (Lionurus) carapinus \\
\hline 11 & 5240313 & 48 & 15 & 4.8 & 7 & 14 & Coryphaenoides (Chalinura) leptolepis \\
\hline 12 & 1190844 & 48 & 16 & 4.8 & 6 & 45 & Coryphaenoides (Nematonurus) armatus \\
\hline 13 & 1190851 & 48 & 16 & 4.8 & 4 & 26 & Coryphaenoides (Nematonurus) armatus \\
\hline 14 & 1190868 & 48 & 16 & 4.9 & 9 & 43 & Coryphaenoides (Nematonurus) armatus \\
\hline 15 & 1190901 & 31 & 16 & 4.4 & 7 & 23 & Bathysaurus mollis \\
\hline 16 & 1191001 & 35 & 14 & 4.4 & 8 & 56 & Coryphaenoides (Chalinura) profundicolus \\
\hline 17 & 1191107 & 38 & 11 & 5.1 & 8 & 21 & Echinomacrurus mollis \\
\hline 18 & 1217431 & 31 & 21 & 4.9 & 3 & 20 & Echinomacrurus mollis \\
\hline 19 & 1217702 & 21 & 20 & 4.1 & 11 & 61 & Coryphaenoides (Chalinura) profundicolus \\
\hline 20 & 1217901 & 22 & 21 & 4.6 & 10 & 57 & Bathyonus laticeps \\
\hline 21 & 1218901 & 20 & 24 & 4.6 & 8 & 17 & Coryphaenoides (Chalinura) profundicolus \\
\hline 22 & 5051501 & 49 & 15 & 4.5 & 5 & 13 & Coryphaenoides (Nematonurus) armatus \\
\hline 23 & 5071101 & 49 & 15 & 4.8 & 5 & 34 & Coryphaenoides (Nematonurus) armatus \\
\hline 24 & 5081101 & 49 & 14 & 4.4 & 4 & 23 & Coryphaenoides (Nematonurus) armatus \\
\hline 25 & 5091001 & 49 & 14 & 4.3 & 5 & 48 & Coryphaenoides (Nematonurus) armatus \\
\hline 26 & $94 / 92 / 04$ & 50 & 14 & 4 & 6 & 162 & Coryphaenoides (Nematonurus) armatus \\
\hline 27 & $94 / 92 / 07$ & 50 & 14 & 4 & 4 & 62 & Coryphaenoides (Nematonurus) armatus \\
\hline 28 & $94 / 92 / 14$ & 50 & 14 & 4.1 & 6 & 86 & Coryphaenoides (Nematonurus) armatus \\
\hline 29 & 1260012 & 20 & 31 & 4.5 & 11 & 23 & Bathyonus laticeps \\
\hline 30 & 1260023 & 20 & 31 & 4.5 & 12 & 39 & Bathyonus laticeps \\
\hline 31 & 1260033 & 20 & 31 & 4.6 & 10 & 36 & Bathyonus laticeps \\
\hline 32 & 1260048 & 20 & 21 & 4.6 & 10 & 26 & Bathymicrops regis \\
\hline 33 & 1260057 & 20 & 31 & 4.6 & 10 & 22 & Bathymicrops regis \\
\hline 34 & 1260066 & 20 & 31 & 4.6 & 12 & 34 & Porogadus sp. \\
\hline 35 & 5320101 & 48 & 16 & 4.9 & 5 & 11 & Coryphaenoides (Chalinura) leptolepis \\
\hline 36 & 5320124 & 48 & 16 & 4.9 & 3 & 14 & Coryphaenoides (Nematonurus) armatus \\
\hline 37 & 5320128 & 48 & 17 & 4.9 & 6 & 15 & Coryphaenoides (Nematonurus) armatus \\
\hline 38 & 5320503 & 48 & 16 & 4.9 & 5 & 19 & Coryphaenoides (Chalinura) leptolepis \\
\hline 39 & 5360201 & 38 & 12 & 4.9 & 5 & 18 & Bathypterois longipes \\
\hline 40 & 5360301 & 35 & 13 & 4.8 & 10 & 24 & Bathymicrops regis \\
\hline 41 & 5360302 & 35 & 13 & 4.9 & 6 & 20 & Coryphaenoides (Nematonurus) armatus \\
\hline 42 & 5360701 & 31 & 16 & 4.4 & 8 & 24 & Coryphaenoides (Nematonurus) armatus \\
\hline 43 & 5360702 & 31 & 16 & 4.4 & 4 & 6 & Coryphaenoides (Nematonurus) armatus \\
\hline 44 & 5360703 & 31 & 16 & 4.4 & 6 & 17 & Coryphaenoides (Nematonurus) armatus \\
\hline \multirow[t]{2}{*}{45} & 5360704 & 31 & 16 & 4.4 & 6 & 26 & Coryphaenoides (Nematonurus) armatus \\
\hline & & & & & Total: & 1592 & \\
\hline
\end{tabular}

\section{MATERIALS AND METHODS}

The ichthyofaunal study was based on data from 25 abyssal samples taken by a 45 foot $(13.7 \mathrm{~m})$ semiballoon otter trawl (OTSB) from 4002 to $5440 \mathrm{~m}$ soundings in the area $20^{\circ} 08.9^{\prime}$ to $50^{\circ} 15.2^{\prime} \mathrm{N}$ and $11^{\circ} 17^{\prime}$ to $31^{\circ} 17.4^{\prime} \mathrm{W}$ during the period 1976 to 1995 (Tables 1 \& 2). The dimensions, construction, method of fishing and sampling limitations of this trawl have been de- tailed earlier (Merrett \& Marshall 1981, Merrett 1987, 1992, Rice et al. 1991). Tows were of a nominal $3 \mathrm{~h}$ duration on the sea-bed and took some 10 to $12 \mathrm{~h}$ from deployment to recovery. Acoustic monitoring of the tow was not always possible and often not practicable as, in all but ideal surface conditions, the net was at the limit of acoustic telemetry (in excess of $11 \mathrm{~km}$ astern of the ship when on the bottom). Bottom contact time to lift off was therefore estimated following standard pro- 
Table 2. Condensed catch characteristics from 45 samples from the eastern North Atlantic indicating (a) family composition ranked by species richness and (b) the dominant species ranked by abundance. SL: standard length; TL: total length

\begin{tabular}{|c|c|c|c|c|c|c|}
\hline (a) Family & Species & (b) Dominant species & Family & \multicolumn{2}{|c|}{ Overall } & $\begin{array}{l}\text { Max. size } \\
\quad(\mathrm{cm})\end{array}$ \\
\hline Ophidiidae $(\mathrm{O})$ & 9 & Coryphaenoides (Nematonurus) armatus & M & 415 & 26.1 & $102 \mathrm{TL}$ \\
\hline Aphyonidae & 7 & Coryphaenoides (Chalinura) leptolepis & M & 299 & 18.8 & $68 \mathrm{TL}$ \\
\hline Ipnopidae (I) & 6 & Bathypterois longipes & I & 146 & 9.2 & $25 \mathrm{SL}$ \\
\hline Macrouridae (M) & 6 & Coryphaenoides (Chalinura) profundicolus & M & 143 & 9.0 & $126 \mathrm{TL}$ \\
\hline Alepocephalidae & 4 & Bathymicrops regis & 1 & 108 & 6.8 & $12 \mathrm{SL}$ \\
\hline Zoarcidae & 2 & Bathyonus laticeps & $\mathrm{O}$ & 86 & 5.4 & $24 \mathrm{SL}$ \\
\hline Gigantactinidae & 1 & Echinomacrurus mollis & M & 82 & 5.2 & $47 \mathrm{TL}$ \\
\hline Monognathidae & 1 & Coryphaenoides (Lionurus) carapinus & M & 36 & 2.3 & $39 \mathrm{TL}$ \\
\hline Liparidae & 1 & Bathysaurus mollis & $\mathrm{B}$ & 24 & 1.5 & $100 \mathrm{SL}$ \\
\hline Synaphobranchidae & 1 & Porogadus sp. & $\mathrm{O}$ & 21 & 1.3 & $32 \mathrm{TL}$ \\
\hline Bathysauridae (B) & 1 & & & & & \\
\hline Stephanoberycidae & 1 & & & & & \\
\hline Total: & 40 & & Total: & 1360 & 85.4 & \\
\hline
\end{tabular}

cedures based on former successful acoustic observations. All depths refer to soundings and, for each station, are given as mid-point values between the upper and lower limits recorded.

The open mouth of the OTSB trawl has potential to collect both pelagic (during descent and ascent) and demersal (benthic and benthopelagic - whilst on the sea-bed) fishes. In the event, however, few midwater captures were made during veering and hauling the trawl. (Species from the midwater ichthyofauna were anyway readily recognisable as they are morphologically and phylogenetically distinct from the demersal fauna [Merrett 1994] and well known in the sampling region from their representation in mouth opening/ closing net catches fished pelagically [Merrett pers. obs.].) Thus, the demersal species were identified to species and counted prior to fixation in $10 \%$ saline formalin.

Measurement of overlap among samples was based on the sample size independent (Kohn \& Riggs 1982) percentage similarity (PS) index, used for consistency with Merrett (1987, 1992), following the formula of Whittaker \& Fairbanks (1958):

$$
\operatorname{PS}_{a b}=100 \sum \min \left(p_{1 a}, p_{i b}\right)
$$

where $p_{i a}=$ the proportion assumed by species $i$ in sample $a$ and $p_{i b}=$ the proportion assumed by species $i$ in sample $b$. The resulting between-sample similarity matrix can be examined by a variety of ordination methods to elucidate the underlying inter-relationships between the sample sites. In the previous analysis of the original 25 samples, the technique of principal co-ordinate analysis was used (Merrett 1992). In this paper we will use non-metric multidimensional scaling (MDS; Kruskal 1964) because this technique has been shown to be better at recovering a known structure, especially when the data set contains a large number of zero entries (Fasham 1977). The samples can be considered as points in an $\mathrm{S}$-dimensional space ( $\mathrm{S}=$ total no. of species) and all ordination techniques are attempts to project the sample points from this high-dimensional space onto a lower dimensional ordination space that will aid interpretation in a way that preserves, as much as possible, the inter-sample relationships in the $\mathrm{S}$-dimensional space. In non-metric multidimensional scaling the degree to which the original inter-sample relationships are preserved is measured by a quantity called the stress and the aim is to try and minimise the stress while keeping the dimensions of the ordination space as low as possible. Some initial tests were carried out with ordination space dimensions from 1 to 4 and it was found that the optimal results were obtained using 3-dimensional (3-D) space. The resulting 3-D ordination was plotted in all 3 combinations of ordination axes and it was found that the space defined by the first 2 axes showed the same general pattern as was found in the earlier analysis (Merrett 1992), while the third axis did not appear to add much extra information. Despite this, the 3-D ordination was preferred to a $2-\mathrm{D}$ one because of the substantially lower stress value (10\% compared to $17 \%)$. In order to investigate the effects of differing sample size, 2 MDS ordinations were carried out, one of the full 45 samples and the other of the earlier set of 25 samples used by Merrett (1992).

\section{RESULTS}

The data matrix was derived from 45 stations spanning $30^{\circ}$ of latitude and $1400 \mathrm{~m}$ of depth (4000 to $5400 \mathrm{~m}$; Fig. 1a). These stations broadly clumped into 3 latitudi- 

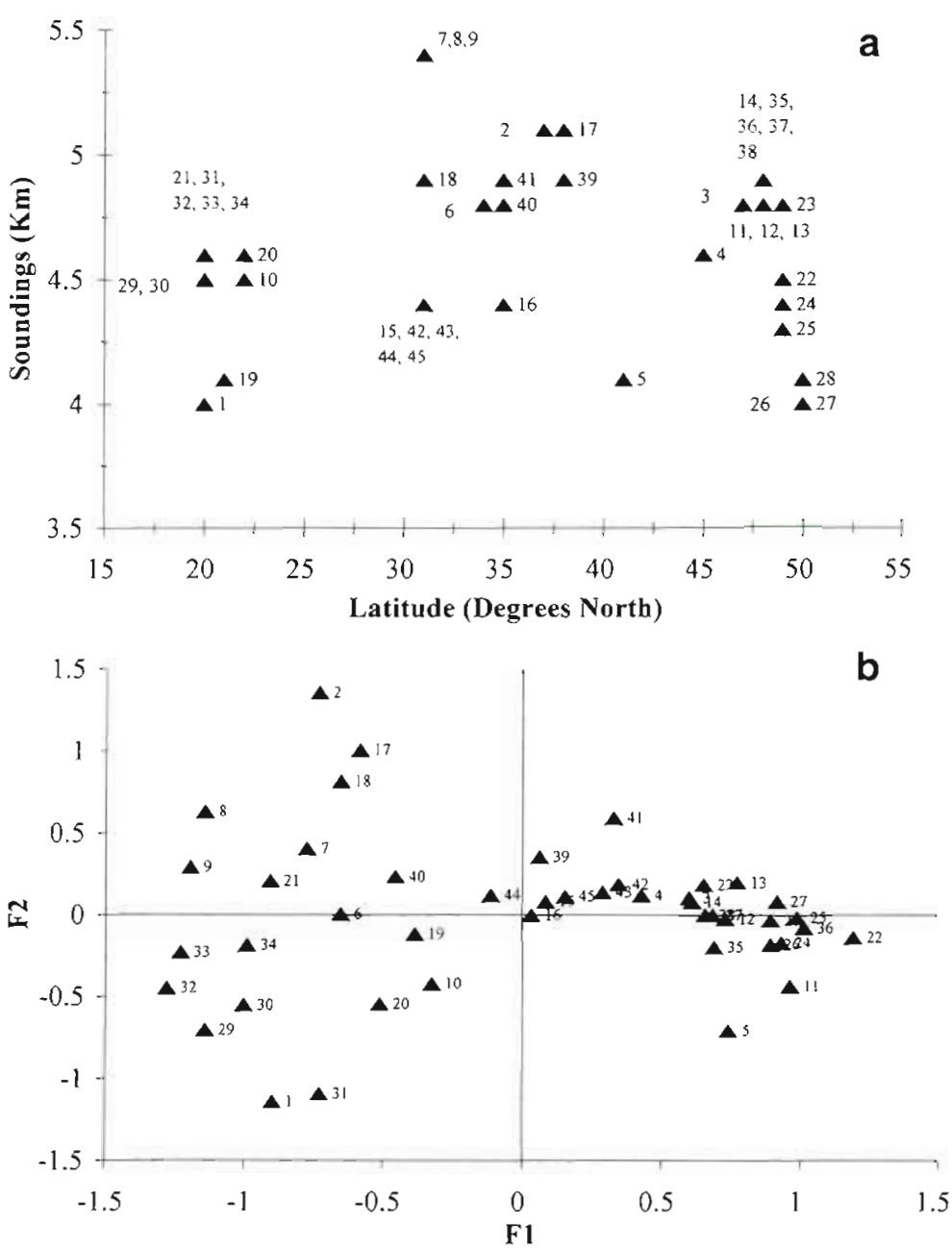

Fig. 1. (a) Plot of 45 semi-balloon trawl station localities by soundings and latitude and (b) sample serial numbers indicated on a plot of 3-D ordination (by multidimensional scaling, MDS) of percentage similarity (PS) indices of the trawl sample matrix

nal blocks, around $20^{\circ}$ to $22^{\circ} \mathrm{N}$ (11 stations), between $31^{\circ}$ and $38^{\circ} \mathrm{N}(16)$ and between $41^{\circ}$ and $50^{\circ} \mathrm{N}(18)$. In all, the collections yielded 1592 specimens representing 40 species of 12 families (Tables $1 \& 2$ ). The Ophidiidae was the best represented family ( 9 species) at these depths, followed by the Aphyonidae (7) and the Ipnopidae and Macrouridae (6 each). Among the dominant species per samples, the order was different. Five of these species were macrourids, 2 each ipnopids and ophidiids, and 1 bathysaurid (Table 2). In abundance, these 10 species accounted for $85.4 \%$ of the total catch.

We use the first 2 axes (F1, F2) of a 3-D MDS analysis of sampling percentage similarities as the basis for interpreting the different sampling variables. The scatter of points over the whole $F 2$ range in the negative $F 1$ half of the plot (Fig. 1b) was more widely and evenly spread than occurs over the positive F1 range, where the points were contained within much closer F2 axis limits. Labelling the points of this plot with sample depth (Fig. 2a) showed that, in the negative F1 range, the distribution over the F2 axis was broadly arranged by depth. The samples from the deepest stations ( $>5.0 \mathrm{~km}$ depth) occurred in the upper left quadrant of the graph, while the shallower ones fall into the lower left quadrant. This was unlike the distribution over the positive $F 1$ range, where no bathymetric ordering is evident.

Latitudinal patterns were more complex (Fig. 2b). All but one of the most southerly stations $\left(20^{\circ}\right.$ to $\left.22^{\circ} \mathrm{N}\right)$ were located in the bottom left quadrant of the plot, while those north of $40^{\circ} \mathrm{N}$ were centrally placed with respect to the $\mathrm{F} 2$ axis, across the highest $F 1$ values. The remaining stations $\left(31^{\circ}\right.$ to $38^{\circ} \mathrm{N}$ ) were spread over the positive $\mathrm{F} 2$ range and relatively broadly along the $F 1$ axis. Noteworthy here was the spread of samples from $31^{\circ} \mathrm{N}$, which will be considered separately below (see 'Discussion').

Turning to the biological variables, samples showing higher species richness were generally located in the negative $F 1$ range (3 to $15 \mathrm{spp}$. overall). There was a transition around $F 1=0$, in the positive direction, to mostly lower values (Fig. 3). Low specimen abundance among these samples generally (mean 35.4, range 156, SD 27.3) resulted in the likelihood of greater variation in species richness per sample than might be the case with larger catches, due to the weak, but significant ( $5 \%$ level), correlation between abundance and species richness per sample (Table 1). Comparison of species richness per F1 interval across the F1 range of the 3-D MDS plot revealed further detail (Fig. 3). The number of species common to more than one interval were evidently broadly similar among the negative $F 1$ intervals towards 0 , with the frequency of unique species in each division decreasing in that direction. The frequency of 'common' species decreased markedly in the positive direction from 0 , with unique species only occurring in the +0.5 to +1 interval. The 15 samples in the +0.5 to +1 interval were latitudinally concentrated and the ichthyofauna was represented by a high proportion of unique species $(0$ to $-1.5,10$ species unique; +0.5 to 1,6 unique).

The distribution of dominant species per sample (selected subjectively on overall commonness of representation where co-dominance of species per sample occurred; listed in Table 2) among the catches overall 

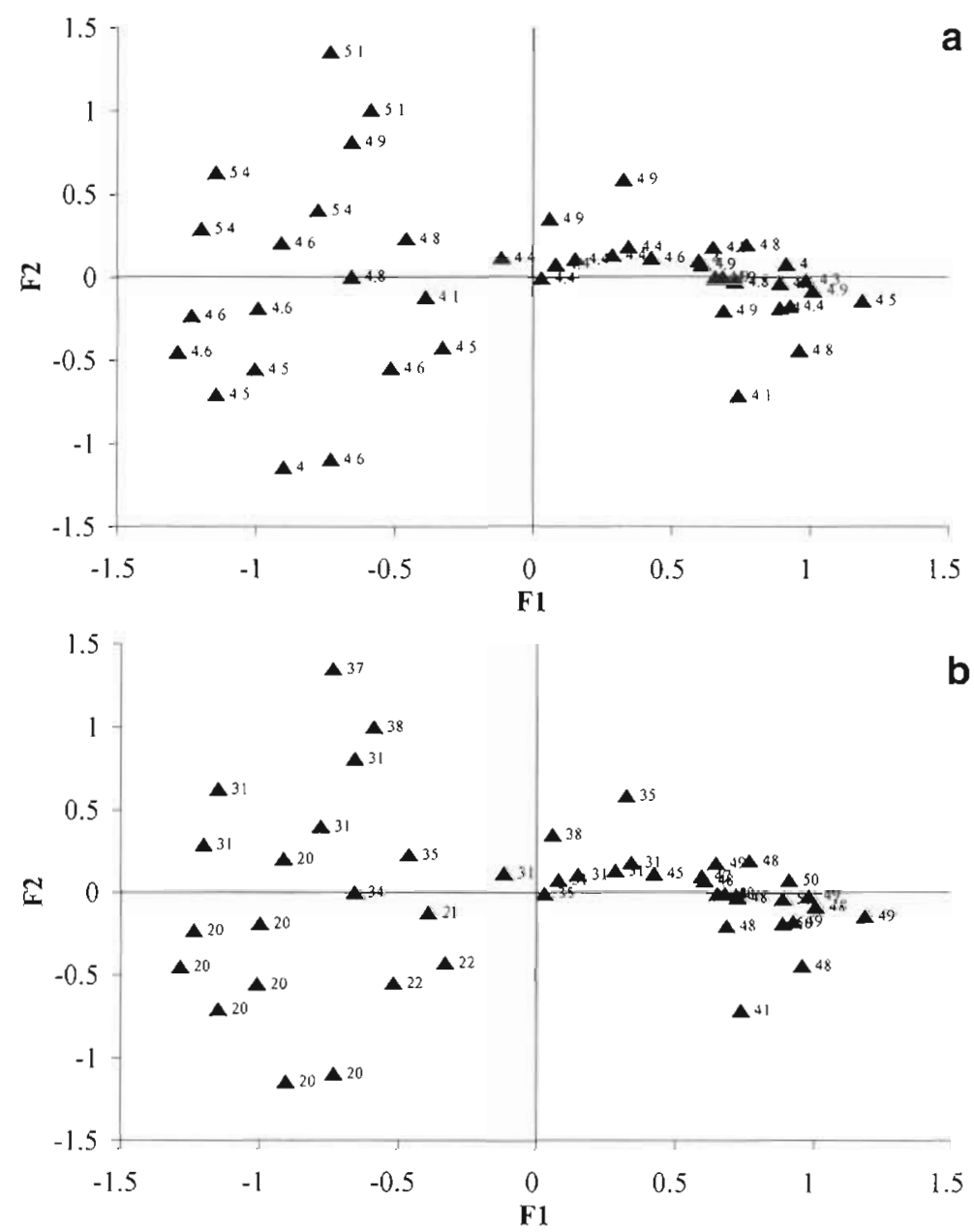

Fig. 2. Plot of 3-D ordination (by MDS) of PS indices of the trawl sample matrix with (a) sample depth (km) and (b) latitude indicated whilst Porogadus sp. (8) dominated a single sample only in the negative quadrant.

\section{DISCUSSION}

Previous analyses of sub-sets of these data (Merrett 1987, 1992) indicated the importance of an ichthyofaunal divide around $38^{\circ}$ to $41^{\circ} \mathrm{N}$, together with the complexity of the association of bathymetry and latitude with sample composition. The data from 25 samples indicated a congruence between the grouping of samples based on principal co-ordinates analysis of the percentage similarity matrix (PCA, biological data) and that derived from locality data alone (latitude and sounding, Merrett 1992, Fig. 2 therein). This similarity indicated that the first 2 eigenvectors of the PCA were correlated with latitude and soundings respectively and that these physical variables must be considered together in explaining the biological distributions. The MDS ordination of the 25 samples gave broadly similar results to the previous PCA (Merrett 1992).

With 45 samples in the data matrix, the situation is rather more complex than for an MDS for the earlier 25 samples. The correlation of the F1 axis with latitude was still strong (Fig. 2b). In fact the correlation between latitude and the F1 co-ordinate suggested that more variation occurred over the negative $F 1$ range ( 8 species) than over the positive F1 range (5) (Fig. 4). Hence, in the positive F1 range Coryphaenoides (Nematonurus) armatus (1) was the most frequently dominant species, with $C$. (Chalinura) leptolepis (2) and Bathysaurus mollis (4) occurring as dominant species only in this range. Coryphaenoides (Chalinura) profundicolus (3) and Bathypterois longipes (5) are species which dominated sporadically across a large part of the overall $F 1$ axis. In the negative $F 1$ range, C. (Lionurus) carapinus (6) and $\mathrm{Ba}$ thyonus laticeps (7) dominated samples only in the negative F2 range, whilst Echinomacrurus mollis (10) dominated only in the positive part of this range. Bathymicrops regis (9), a diminutive species, occurred throughout both F2 quadrants,

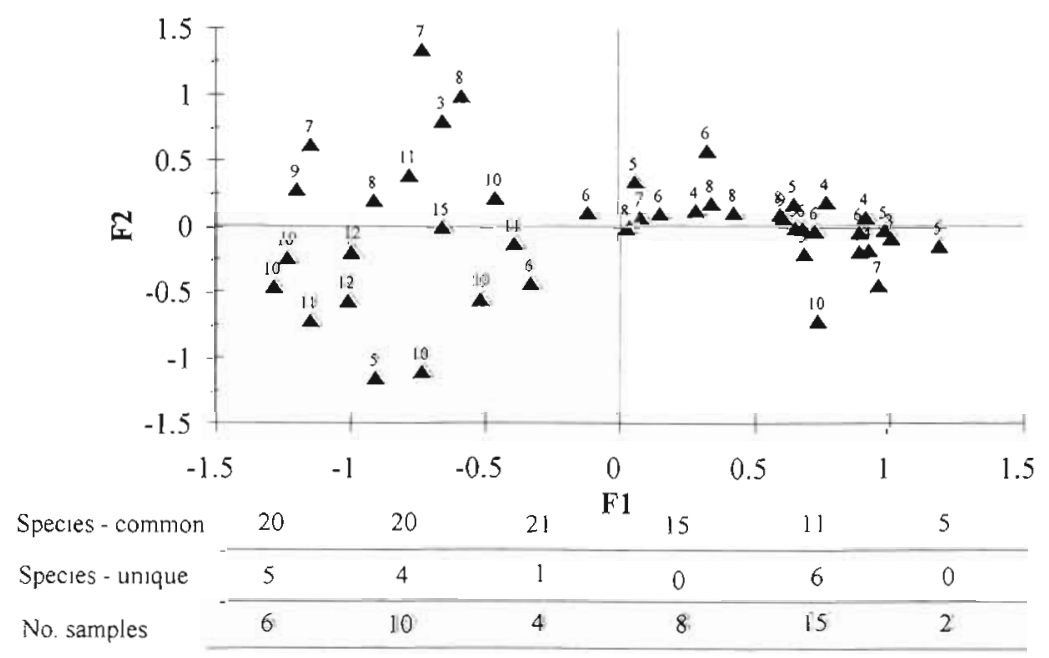

Fig. 3. Plot of 3-D ordination (by MDS) of PS indices of the trawl sample matrix with species richness indicated. Below, values are given for the total species richness per 3-D MDS F1 range interval, as species common to more than one interval plus those unique to each range, together with sample frequency per range interval 


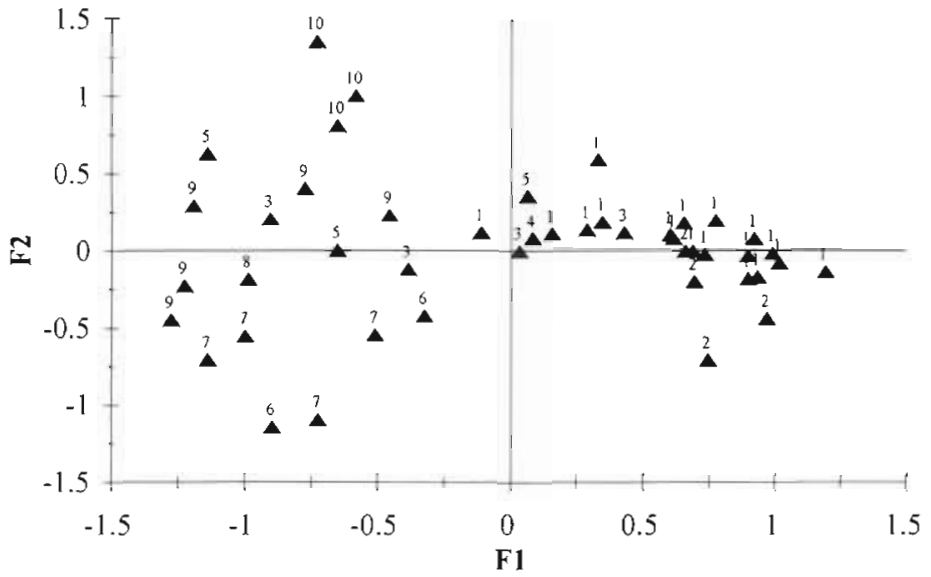

Fig. 4. Plot of 3-D ordination (by MDS) of PS indices of the trawl sample matrix with dominant species indicated (see text for species order)

ples in group 3 in Fig. 5. Its lack of unique species representatives may reflect the relatively broad latitudinal span and narrow depth variation of the component stations.

Similarly, species dominance per sample varied in groups 1 and 2, but were largely monopolized by Coryphaenoides (Nematonurus) armatus in the other 2 groups. Moreover, the abyssal assemblages beneath high surface productivity zones (a northerly region of deep winter mixing [group 4] and a southerly area under the influence of strong upwelling [group 1]) tended towards greater separation along the F1 axis than did the upper and lower abyssal assemblages in mid-latitudes (groups 2 and 3; cf. Merrett 1992).

The broad scatter of points over the ranges of variables studied was indicative of the loose

was slightly higher for the full 45 stations $(r=0.87$ ) than for the original 25 stations $(r=0.82)$. However the correlation between the $F 2$ co-ordinate and depth was weakened by adding the extra stations (r reduced from 0.65 to 0.51 ), although the correlation was still significant at the $1 \%$ level. The question now is: how have the additional data effected this alteration? A summary of the current findings is shown in Fig. 5, where the samples are segregated by locality (latitude, longitude and depth) on the 3-D MDS scatter plot to approximate to the 4 groupings (1: upper abyssal, low latitude; 2 : lower abyssal, mid-latitude; 3: mid-abyssal, mid-latitude; and 4: upper/mid-abyssal, high latitude) distinguished previously (Merrett 1992). Addition of the new data has broadened the scatter of points, tending to cause the groupings to coalesce. Nonetheless, some trends are evident. Species richness in groups 1 and 2 was generally high as mentioned above, somewhat contrasting with groups 3 and 4 . This is borne out by the overall trend in species richness indicated in Fig. 3, notwithstanding the effect of variable sample frequency per F1 axis division. This trend in declining species richness in a poleward direction is broadly consistent with those reported from this and other environments (Marshall 1963. Lindsey 1966, Roy et al. 1998) and, more directly, with the generality of depth-latitude co-variation among eastern Atlantic marine fishes (Macpherson \& Duarte 1994). Noteworthy in this case is the seeming intermediate position of those stations which occurred in the 0 to $+0.5 \mathrm{~F} 1$ range division in Fig. 3. This interval contained samples from 4.4 to $4.9 \mathrm{~km}$ deep and from $31^{\circ}$ to $45^{\circ} \mathrm{N}$, which are almost congruent with the sam- nature of the sample groupings. This contrasts with earlier findings of relatively abrupt faunal boundaries, seemingly evident from the smaller sample sizes. The most cohesive grouping was still that set of samples located in the 4.0 to $4.9 \mathrm{~km}$ depth range and, with the exception of 2 samples (serial nos. 4 and 5: $45^{\circ} \mathrm{N}, 4.6$ $\mathrm{km}$ depth; $41^{\circ} \mathrm{N}, 4.1 \mathrm{~km}$ respectively), located north of $45^{\circ} \mathrm{N}$. This broadly confirms the results previously suggested by PCA analysis (Merrett 1992). Active, predatory species of large adult size and a high fecundity, likely 'all-at-once' reproductive strategy were again associated with this grouping (cf. Merrett 1987).

The influence of latitude on other variables was removed by examining the 9 longitudinally spread sta-

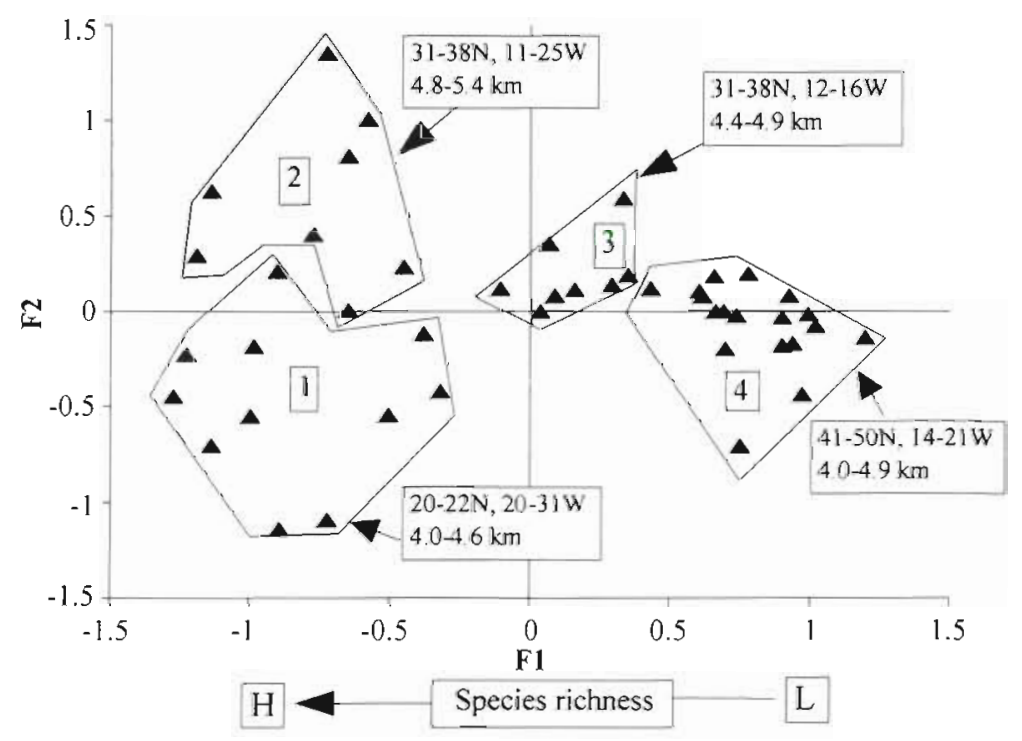

Fig. 5. Plot of 3-D ordination (by MDS) of PS indices of the trawl sample matrix with groupings ( 1 to 4 ) delineated by area and soundings. The direction of latitudinal change in species richness is also indicated. $\mathrm{H}$ : high; L: low 


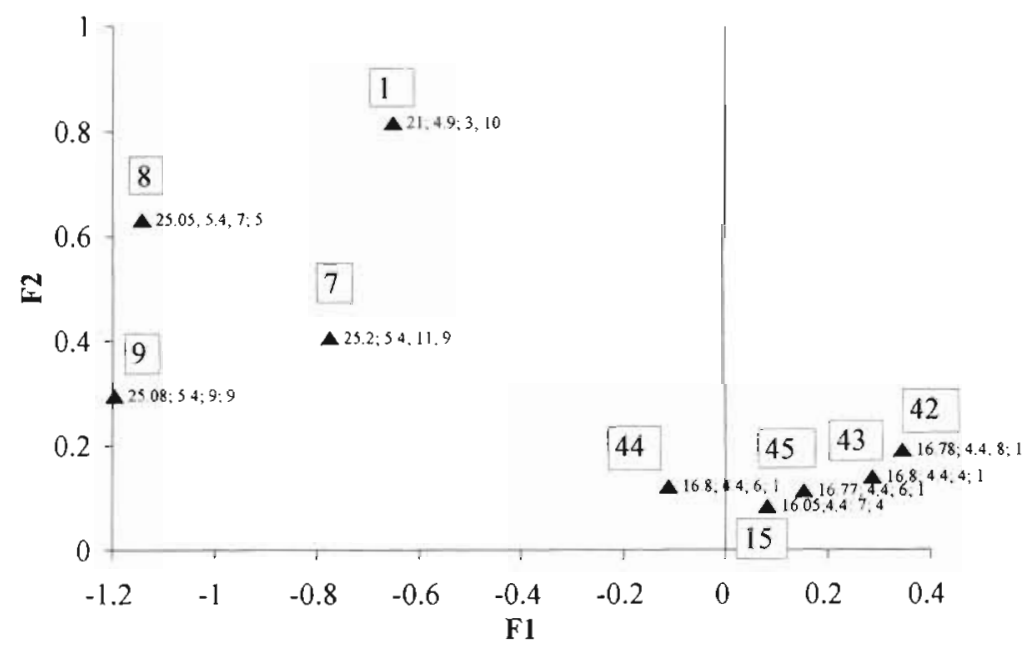

Fig. 6. Plot of 3-D ordination (by MDS) of selected PS indices of the trawl sample matrix along latitude $31^{\circ} \mathrm{N}$, summarizing longitude, depth, species richness and dominant species respectively for each sample. (Boxed numbers indicate sample serial numbers from Fig. 1 and Table 1)

however, that several of the more northerly samples in the positive F1 half of the 3-D MDS plot were collected deep at around 4.8 to $4.9 \mathrm{~km}$. These had faunal characteristics similar to those of the shallower (4.4 $\mathrm{km}) 31^{\circ} \mathrm{N}$ samples. Equally, the southerly stations $\left(20^{\circ}\right.$ to $\left.22^{\circ} \mathrm{N}\right)$ were in the 4.1 to 4.6 $\mathrm{km}$ depth range and yet were very different in their ichthyofaunal characteristics. The causal link originally proposed between surface productivity and abyssal ichthyofaunal life-history parameters (Merrett 1987) remains consistent with these results. Since oceanic standing crop decreases exponentially with depth (Angel \& Baker 1982), a $1000 \mathrm{~m}$ bathymetric change in living depth, and therefore in food availability, seems fully consistent with the alteration in life-history patterns described above. Likewise, the highly seasonal northerly region north of around $40^{\circ} \mathrm{N}$ can

tions at $31^{\circ} \mathrm{N}$ in the 3-D MDS scatter plot (Fig. 6). All samples (5) at $16^{\circ} \mathrm{W}$ and $4.4 \mathrm{~km}$ depth had a species richness of 4 to 8 per sample; Coryphaenoides (Nematonurus) armatus dominated 4 of these and Bathysaurus mollis the other one. Located in the positive F1 half of the range, these samples tended to link the lower latitude faunal groupings with the tightly clustered 'pan handle' of northerly samples. The remaining samples, less tightly clustered and located in the more negative part of the F1 range and positive part of the $F 2$ range, were from stations occupied farther west $\left(21^{\circ}\right.$ to $\left.25^{\circ} \mathrm{W}\right)$ and appreciably deeper (4.9 to $\left.5.4 \mathrm{~km}\right)$. Species richness among them was variable ( 3 to 11 species per sample) with Bathypterois longipes (1 sample), Bathymicrops regis (2) and Echinomacrurus molLis (1) dominating.

Ecologically, the 2 groups of dominant species identified above represent the extremes of individual maximum size, foraging and reproductive strategies noted earlier (Merrett 1987, 1992) for species dominating on either side of the putative faunal divide located around $38^{\circ}$ to $41^{\circ} \mathrm{N}$. Dominant to the north of $41^{\circ} \mathrm{N}$, Coryphaenoides (Nematonurus) armatus and Bathysaurus mollis are large (Table 2), robust and active species which feed on large benthopelagic prey and have high fecundity. Dominant to the south of $38^{\circ} \mathrm{N}$, Bathypterois longipes (benthic), Bathymicrops regis (benthic) and Echinomacrurus mollis (weakly benthopelagic) are microphagous bottom feeders of small adult size (Table 2), which have low fecundity and batch spawning tendencies.

At first sight, the overall data plot seems to confuse the earlier conclusion of a faunal boundary zone around the latitude of $40^{\circ} \mathrm{N}$. It should be remembered, be expected to possess different productivity characteristics to those existing in one of the major global centres of upwelling. Thus, while addition of 20 more data sets brings out the complexity of the abyssal asssemblage structure in the eastern North Atlantic region, the role of surface production and its influence at different bathymetric levels even within the abyssal zone is maintained (cf. Roy et al. 1998).

The evolution of this line of ongoing research shows plainly how sample size affects results, in both qualitative (in this case locality choice and distribution patterns) and quantitative (integrity of faunal groups) ways. Thus, while species richness evidently decreases in a northerly direction and the larger, more active benthopelagic, as opposed to benthic, fishes dominate in the north as originally observed, the abyssal assemblage structure has turned out to be much more complex than first indications and published interpretations suggested.

Acknowledgement. Dr R. L. Haedrich's (Memorial University, Newfoundland) encouraging discussion of the early results greatly helped the preparation of the manuscript.

\section{LITERATURE CITED}

Anderson ME, Crabtree RE, Carter HJ, Sulak KJ, Richardson MD (1985) Distribution of the demersal fishes of the Caribbean Sea found below 2000 meters. Bull Mar Sci 37 : $794-807$

Angel MV, Baker AdeC (1982) Vertical distribution of the standing crop of plankton and micronekton at three stations in the Northeast Atlantic. Biol Oceanogr 2:1-30

Fasham MJR (1977) A comparison of nonmetric multidimensional scaling, principal components and reciprocal averaging for the ordination of simulated coenoclines, and 
coenoplanes. Ecology 58:551-561

Kohn AJ, Riggs AC (1982) Sample size dependence in measures of proportional similarity. Mar Ecol Prog Ser 9:147-151

Kruskal JB (1964) Multidimensional scaling by optimising goodness of fit to a nonmetric hypothesis. Psychometrika 29:1-27

Lindsey CC (1966) Body sizes of poikilotherm vertebrates at different latitudes. Evolution 20:456-465

Macpherson E, Duarte CM (1994) Patterns in species richness, size, and latitudinal range of East Atlantic fishes. Ecography 17:42-248

Marshall NB (1963) Diversity, distribution and speciation of deep-sea fishes. In: Harding JP, Tebble N (eds) Speciation in the sea. Syst Assoc, Publ No. 5, p 181-185

Merrett NR (1987) A zone of faunal change in assemblages of abyssal demersal fish in the eastern North Atlantic: a response to seasonality in production? Biol Oceanogr 5 : $137-151$

Merrett NR (1992) Further evidence on abyssal demersal ichthyofaunal distribution in the eastern North Atlantic, with special reference to Coryphaenoides (Nematonurus) armatus (Macrouridae). J Mar Biol Assoc UK 72:5-24

Merrett NR (1994) Reproduction in the North Atlantic oceanic ichthyofauna and the relationship between fecundity and

Editorial responsibility: Otto Kinne (Editor),

Oldendorf/Luhe, Germany species' sizes. Environ Biol Fishes 41:207-245

Merrett NR, Haedrich RL (1997) Deep-sea demersal fish and fisheries. Chapman \& Hall, London

Merrett NR, Marshall NB (1981) Observations on the ecology of deep-sea bottom-living fishes collected off northwest Africa $\left(08^{\circ}-27^{\circ} \mathrm{N}\right)$. Prog Oceanogr 9:185-244

Rice AL, Billett DSM. Thurston MH, Lampitt RS (1991) The Institute of Ocearlographic Sciences biology programme in the Porcupine Seabight: background and general introduction. J Mar Biol Assoc UK 71:281-310

Roy K, Jablonski D, Valentine JW, Rosenberg G (1998) Marine latitudinal diversity gradients: tests of causal hypothesis. Proc Natl Acad Sci USA 95:3699-3702

Sulak K (1982) A comparative taxonomic and ecological analysis of temperate and tropical demersal deep-sea fish faunas in the western North Atlantic. PhD thesis, University of Miami, p 181

Sündermann J (ed) (1986) Landolt-Bornstein numerical data and functional relationships in science and technology. New series. Group V: Geophysics and space research, 3. Oceanography, Subvol a. Springer-Verlag, Berlin

Whittaker RH, Fairbanks CW (1958) A study of plankton copepod communities in the Columbia Basin, southeasterm Washington. Ecology 39:46-65

Submitted: May 8, 1998; Accepted: July 31, 1998

Proofs received from author(s): October 19,1998 